\title{
Making Sense of an Elusive Concept: Academics' Perspectives of Quality in Higher Education
}

Lazarus Nabaho, ${ }^{*}$ a Jessica Norah Aguti, ${ }^{b}$ and Joseph Oonyu ${ }^{b}$

aUganda Management Institute, Kampala, Uganda

bMakerere University, Kampala, Uganda

Submitted: August 8, 2017 | Peer reviewed: September 5, 2017 | Accepted: September 28, 2017|

Published: November 1, 2017

\begin{abstract}
Objective: Since the 1990s studies on how stakeholders in higher education perceive quality have burgeoned. Nevertheless, the majority of studies on perception of quality in higher education focus on students and employers. The few studies on academics' perceptions of quality in higher education treat academics as a homogeneous group and, therefore, do not point out crossdisciplinary perspectives in perceptions of quality. This article explores how academics across six disciplines perceive quality in higher education.

Method: The article is anchored in the interpretivist paradigm. Data was collected from 14 purposely selected academics at Makerere University in Uganda and analyzed using thematic analysis.

Results: The findings show that academics perceive quality in higher education as transformation, fitness for purpose, and exceptional. The findings further demonstrate that a stakeholder group or an individual stakeholder can subscribe to a notion of quality in higher education but voice divergent views on its variants. Similarly, the academic discipline, the perceived purpose of higher education, and the problems within a higher education system have an influence on stakeholders' conception of quality in higher education.
\end{abstract}

Conclusions: From the findings it can be inferred that quality in higher education defies a single definition and that stakeholders' perceptions of quality do not take place in a vacuum.

Implication for Theory and/or Practice: The multidimensional nature of quality and the contestations around it necessitate a multidimensional approach to assuring and assessing it.

Keywords: academics, perceptions, quality, higher education

\section{Introduction}

From the mid-1980s, quality has become a topical issue in higher education (Elassy, 2015; Liu, 2016; Nabaho, Aguti, \& Oonyu, 2016; Sarrico, Rosa, Teixeira, \& Cardoso, 2010). The emergence of the extrinsic dimension of quality in higher education has precipitated studies on how the stakeholders in higher education perceive quality (Jungblut, Vukasovic, \& Stensaker, 2015). Nonetheless, academics—as a stakeholder group_have received less attention in studies on perception of quality in higher education (Barandiaran-Galdós, Barrenetxea Ayesta, CardonaRodríguez, Mijangos del Campo, \& Olaskoaga-Larrauri, 2012; Cardoso, Rosa, \& Stensaker, 2016) compared to studies on students and employers. The limited scholarship is amidst the

*Author correspondence: nabaho1@yahoo.com

Suggested Citation: Nabaho, L., Aguti, J. N., \& Oonyu, J. (2017). Making sense of an elusive concept: Academics' perspectives of quality in higher education. Higher Learning Research Communications, 7(2), 25-45. http://dx.doi.org/10.18870/hlrc.v7i2.383 
recognition that "quality lies at the heart of academic work ... [and the] views of academics on issues around quality in higher education are critical to the debate" (Watty, 2006a, p. 24) and the belief that academics' perceptions pertaining to quality may explicitly or implicitly support institutional efforts of quality improvement (Giertz, 2000).

The few studies on how academics perceive quality in higher education focus on academic accountants (Kalayci, Watty, \& Fahriye, 2012; Watty, 2005, 2006a, 2006b), treat academics as a homogeneous group, and hence do not point out cross-disciplinary perspectives in perceptions of quality (Brown, 2010; Lomas, 2007; Cardoso et al., 2016); these studies also focus on the European and Australian higher education contexts. Therefore, little is known about whether accounting academics' perceptions of quality in higher education are compatible with those of academics from other disciplines or whether there are cross-disciplinary and cross-cultural variations in academics' perceptions of quality. As a result Kalayci et al. (2012, p. 17) implore scholars to consider "researching further the attitudes and beliefs of academics about quality across different disciplines and from different countries, to expand our understanding of this complex global issue in higher education." Schindler, Welzant, Puls-Elvidge, and Crawford (2015, p.9) echo Kalayci et al. by suggesting studies that seek to determine "whether the terms, quality and quality assurance, are applicable across cultures and, if so, whether there are distinct regional and national meanings of these terms."

More so, within African, studies have been conducted on quality assurance and assessment (Kadhila, 2012; Materu \& Righetti, 2010; Mhlanga, 2008; Nabaho et al., 2016; Nega, 2012; Utuka, 2012). These studies enhance our understanding of the quality assurance (and assessment) approaches at institutional and national levels. However, it is arguable whether the current quality assurance approaches are context-sensitive and/or compatible with the stakeholders' perceptions of quality in higher education. Quite often higher education systems of developing countries have been faulted for, inter alia, importing and applying quality assurance models from the United States and continental Europe without balancing the global and local contexts (Mhlanga, 2008; Williams, 2013). The political, ideological, cultural, and socio-economic factors that shaped the quality assurance models in advanced economies are different from those that obtain in transitional economies. Within the quality discourse, there is ample evidence from several jurisdictions to the effect that a one-size-fits-all approach to quality improvement and quality assurance is likely to fail (Kalayci et al., 2012). Indeed, there is truth in the assertions by scholars such as Schindler et al. (2015) and Elassy (2015) that quality assurance approaches in higher education should be informed by context-specific rather than isomorphism-driven quality assurance methodologies.

Therefore, this interpretivist article answers the following research question: How is quality in higher education perceived by academics across the different disciplines at Makerere University in Uganda? The article comprises six sections. After this introduction, the second section presents the status of quality assurance and assessment in higher education in Africa, followed by a review of literature on academics' perceptions of quality in higher education. The next section presents the methods. The fifth section presents the results, while the final section discusses the results and draws conclusions.

\section{Quality Assurance and Assessment in Higher Education in Africa}

In Africa, quality assurance in higher education-“a continuous process of evaluating (assessing, monitoring, guaranteeing, maintaining, and improving) the quality of a higher education system, institutions or programs" (Vlãsceanu, Grünberg, \& Pârlea, 2007, p.74)—is as old as the first universities (Materu, 2007; Materu \& Righetti, 2010; van der Bank \& Popoola, 
2014). The first pre-independence universities in Africa were affiliated to the universities in the colonizing countries (Materu, 2007). As a result of affiliation, the universities were part of the British, French, Portuguese, or other quality assurance systems through their partner universities (Materu, 2007). Affiliation provided African countries with "educational qualifications comparable to the academic standards, culture, and character of European universities of that time" (Materu, Obanya, \& Righetti, 2011, p.195).

The period 1960 to 1970 was an unprecedented decade on the African political and educational landscape because of two developments: attainment of independence by most countries and establishment of national universities. These developments undoubtedly altered the texture of quality assurance from affiliation to mentorship of new universities by universities in the former colonizing countries, as well as older universities in Africa (Materu \& Righetti, 2010).

The post-1980s occasioned further changes on the African higher education landscape, including heightened demand for higher education; entry of new private entrepreneurs and a massive increase in public and private universities because of increased demand for higher education; increased student enrolment; and reduced funding to the higher education sector (Materu, 2007). These changes occasioned a sharp decline in higher education quality (Mamdani, 2007; Materu, 2007). Governments responded to the quality deficit by establishing national quality assurance agencies to reverse the apparent decline of quality, to regulate new higher education providers, and to promote accountability of universities (Materu \& Righetti, 2010; Shabani, Okebukola, \& Oyewole, 2014). The national quality assurance regimes stipulate national-level and institutional quality assurance mechanisms.

The current configuration of quality assurance in African higher education mirrors the quality assurance methodologies in the advanced higher education systems of Europe, the United States, and Australia. The convergence in quality assurance methodologies is a manifestation of policy borrowing by countries in Africa. At the institutional level, the main quality assurance practices include student evaluation of teaching (Alshamy, 2011; Mhlanga, 2008; Nabaho et al., 2016; Utuka, 2012); pedagogical training (Ezati, Opolot-Okurut, \& Ssentamu, 2014); peer observation of teaching (Mhlanga, 2008); institutional self-assessment (Kadhila, 2012; Materu, 2007; Nega, 2012); monitoring of teaching by academic leaders (Mhlanga, 2008; Nabaho et al., 2016); external examination (Materu, 2007); and tracer studies. In a bid to ensure a nexus between the world of education and the world of work, higher education institutions involve external stakeholders (employers and professional bodies) in the development of academic programs.

At the national level, quality assurance takes the form of accreditation (of both institutions and academic programs) and quality audits (Materu, 2007; Nega, 2012; Utuka, 2012). Quality assurance in Africa occupies a seat at the supranational level. Since 2011 the African Union, in a bid to revitalize higher education on the continent, has embarked on the harmonization of the heterogeneous higher education systems on the continent. The harmonization initiative is envisaged to create an African higher education space along the lines of the Bologna Process in Europe (Nabaho, 2017). In addition to improving the quality of higher education, harmonization is intended to facilitate mutual recognition of degrees and to eliminate the barriers to free mobility of graduates and academics across Africa. A context-specific quality assurance mechanism at continental level is the African Quality Rating Mechanism (AQRM). The dissatisfaction with ranking schemes or league tables, which hinge on prestige and status building rather than major quality concerns on the African continent (such as capacity and relevance), stimulated the development of the AQRM. Under the AQRM higher education institutions assess themselves and compare their performance against similar institutions in 11 areas and on 85 rating items. 
The criteria has an institutional-level dimension (governance and management, infrastructure, finance, and teaching and learning); and a program-level dimension (program planning and management, curriculum development, teaching and learning, assessment, and program results). The AQRM is hypothesized to create a quality culture in higher education institutions.

Within the African higher education landscape, there is a dearth of literature on whether the current quality assurance practices are context-sensitive. A reliable indicator of contextsensitivity is the degree of alignment between the practices and the stakeholders' perceptions of quality in higher education. This suggests that stakeholders' perception(s) of quality in higher education should serve as a precursor to the design or adaptation of borrowed models of quality assurance and assessment. Any attempt to design and implement quality assurance methodologies that are oblivious of the perceptions of quality can be likened to parading the cart before the horse.

\section{Academics' Perceptions of Quality in Higher Education}

Defining quality, especially in higher education, is a challenging endeavor (Elassy, 2015; Liu, 2016; Martin \& Stella, 2007; Schindler et al., 2015; Wittek \& Kvernbekk, 2011). The difficulty in unpacking quality is occasioned by the existence of a plethora of stakeholders in higher education: academics, administrators, students, parents, government, regulatory agencies, and development partners. There is a high likelihood of inter- and intrastakeholder contestations around the definition of quality (Westerheijden, Stensaker, \& Rosa, 2007). Quite often, quality is likened to beauty, which lies in the eye of the beholder (Elassy, 2015; Doherty, 2008; Wittek \& Kvernbekk, 2011), and freedom and justice, which are equally elusive concepts (Liu, 2016). In view of the above, post-1980 scholars of higher education regard quality as a concept that is notoriously elusive (Liu, 2016; Green, 1994; Jonathan, 2000), slippery (Pfeffer \& Coote, 1991), subjective (Doherty, 2008; Harvey \& Green, 1993), stakeholder-relative (Harvey \& Green, 1993), dynamic (Boyle \& Bowden, 1997), multidimensional (Campbell \& Royzsnyai, 2002), and contested (Newton, 2002).

Harvey and Green (1993) have contributed to the quality discourse in higher education by suggesting five discrete but interrelated notions of quality. These are

(a) quality as exceptional (exceeding high standards and passing required standards);

(b) quality as perfection (exhibited through "zero defect" and "consistent and flawless outcome");

(c) quality as fitness for purpose (meaning that the product or service meets the stated purpose, customer specifications, and satisfaction);

(d) quality as value for money (through efficiency and effectiveness, return on investment); and

(e) quality as transformation (in terms of qualitative change, enhancement/empowerment of students or the development of new knowledge). [pp. 11-28]

However, Harvey and Green (1993) regard the above notions of quality in higher education as "not a different perspective on the same thing but different perspectives on different things with the same label" (p. 10).

Generally, studies on the perceptions of quality have been conducted by academics (Brown, 2010; Cardoso et al., 2016; Elassy, 2015; Kalayci et al. 2012; Lomas, 2007; Vann, 2012; Villanueva, 2012; Watty, 2005, 2006a, 2006b). Watty (2005) conducted a study on academic accountants' views of quality in accounting education. The academic accountants believed that accounting education should align with the transformative definition of quality. Relatedly, Lomas 
(2007), using a sample of 20 lecturers from selected U.K. universities, established that most academics perceived quality to be related to fitness for purpose rather than transformation. In a quantitative study on perceptions of quality by students, academics, and employers in the Sultanate of Oman, Zachariah (2007) established that most academics agreed with fitness for purpose, transformation, and excellence as notions of quality in higher education. However, most academics preferred fitness for purpose. In a study conducted at the University of Western Cape in South Africa, Brown (2010) found that most academics favored fitness for purpose as a definition of quality, followed by transformation.

The literature review indicates that disciplinary perspectives have been given little attention in studies on stakeholders' conceptions of quality in higher education. The few disciplinary studies (Kalayci et al. 2012; Watty, 2005, 2006a, 2006b) skew toward accounting academics. Finally, most quality-perception studies focus on higher education systems of advanced economies. This article marks a departure from previous scholarship on the subject because it focuses on a transitional economy with an embryonic quality assurance system and further incorporates disciplinary perspectives in the quality discourse.

\section{Methods}

Before articulating the methods, it is appropriate to sketch the context of Makerere University. Makerere University-the oldest public university in Uganda and in East Africa-was established in 1922 as a technical college. It is located in Kampala, the capital city of the Republic of Uganda. In 1949 it assumed the status of a university college affiliated to the University of London. Under the affiliation arrangement, it offered academic programs leading to the general degrees of the University of London. It became one of the three constituent colleges of the University of East Africa in 1963, and this marked the end of the affiliation arrangement with the University of London. In 1970, by an Act of Parliament, it became an independent university of the Republic of Uganda. By 2013 Makerere University had a student population of 40,000 undergraduate and 3,000 postgraduate students respectively (Makerere University, 2013). Makerere University takes up 53\% of the enrolment in public universities in Uganda. The university comprises 10 colleges, which are structured into schools and teaching departments. As at December 2012, the university had about 1,600 academic staff (Makerere University, 2013).

This article is anchored in the interpretivist paradigm, and we adopted a qualitative research approach. Within the qualitative approach, "the researcher is interested in understanding how participants make meaning of a situation or phenomenon [and] this meaning is mediated through the researcher as an instrument" (Merriam, 2002, p. 6). The qualitative approach considers the quality of participants in the study and the depth of the interviews to be more important than the number of participants. The choice of the qualitative approach was influenced by the research question, which aimed at understanding academics' culturally derived and historically situated interpretations of quality in higher education.

We adopted a purposive sampling technique, using multistage purposive sampling to select representative colleges, schools, departments, and lecturers. Using the humanities and sciences dichotomy, 4 out of 10 colleges were selected. The dichotomy was intended to offer insights as to whether there are similarities and differences in the conceptions of quality in higher education by academics across disciplines. The following colleges were selected: the College of Education and External Studies (CEES) and College of Humanities and Social Sciences (CHUSS), representing the arts domain; and the College of Engineering, Design, Art, and Technology (CEDAT) and the College of Health Sciences (CHS), representing the sciences domain. 
From each college, one school was purposively selected from which two academic departments were also purposively selected. One academic program was purposively selected from each of the sampled departments. The eight programs reflect six disciplines (engineering, dentistry, nursing, education, music and drama, and development studies). From each discipline academics were purposively selected. The following criteria were used to select two academics from each department: (a) a full-time member of staff, (b) a minimum of 3 years in university service, and (c) currently coordinating or having coordinated a course. This brought the total number of academics from whom data was collected to 14 (five female and nine male) after two academics declined to participate in the study. The 14 academics comprised a professor, an associate professor, three senior lecturers and heads of department, six lecturers, and three assistant lecturers. In terms of academic achievement, 10 participants in the study had attained doctoral degrees while four were master's degree holders. Table 1 shows how multistage sampling was used to select the colleges, schools, and departments.

Table 1. Sample Size and Sample Selection for Academics

\begin{tabular}{|c|c|c|c|c|}
\hline College & School & Department & Academic Program & $\begin{array}{l}\text { Number of } \\
\text { participants }\end{array}$ \\
\hline \multirow{2}{*}{ CEES } & \multirow{2}{*}{ Education } & $\begin{array}{l}\text { Humanities and } \\
\text { Language Education }\end{array}$ & $\begin{array}{l}\text { Bachelor of Arts with } \\
\text { Education }\end{array}$ & 2 \\
\hline & & $\begin{array}{l}\text { Science, Technical and } \\
\text { Vocational Education }\end{array}$ & $\begin{array}{l}\text { Bachelor of Science with } \\
\text { Education }\end{array}$ & 1 \\
\hline \multirow{2}{*}{ CHUSS } & \multirow{2}{*}{$\begin{array}{l}\text { Liberal and } \\
\text { Performing } \\
\text { Arts }\end{array}$} & $\begin{array}{l}\text { Philosophy and } \\
\text { Development Studies }\end{array}$ & $\begin{array}{l}\text { Bachelor of Development } \\
\text { Studies }\end{array}$ & 1 \\
\hline & & Performing Arts & $\begin{array}{l}\text { Bachelor of Arts in Drama } \\
\text { and Music }\end{array}$ & 2 \\
\hline \multirow{2}{*}{ CEDAT } & \multirow{2}{*}{ Engineering } & $\begin{array}{l}\text { Civil and Environmental } \\
\text { Engineering }\end{array}$ & $\begin{array}{l}\text { Bachelor of Science in Civil } \\
\text { Engineering }\end{array}$ & 2 \\
\hline & & $\begin{array}{l}\text { Electrical and Computer } \\
\text { Engineering }\end{array}$ & $\begin{array}{l}\text { Bachelor of Science in } \\
\text { Electrical Engineering }\end{array}$ & 2 \\
\hline \multirow{2}{*}{$\mathrm{CHS}$} & \multirow{2}{*}{$\begin{array}{l}\text { Health } \\
\text { Sciences }\end{array}$} & Dentistry & Bachelor of Dental Surgery & 2 \\
\hline & & Nursing & Bachelor of Nursing & 2 \\
\hline Total & & & & 14 \\
\hline
\end{tabular}

Note. CEES = College of Education and External Studies; CHUSS = College of Humanities and Social Sciences; CEDAT = College of Engineering, Design, Art, and Technology; CHS = College of Health Sciences.

Data for the study was collected from April 1 to July 1, 2014, using interviews. Though follow-up questions were asked, the following questions guided data collection:

(a) When we talk of trying to improve quality in higher education, what is it that we should be trying to improve?

(b) What do you trace your beliefs about quality to? Where do your beliefs about quality come from?

All the interviews were conducted in English, and each interview session lasted 45 to 60 minutes. The interviews were conducted in the participants' offices. Analysis of the resultant data was guided by Creswell's (2003) framework for analyzing qualitative data. The initial stage in the data-analysis process was transcription of the interviews. Then the transcripts were read to obtain 
a sense of the data. This process yielded three codes on conceptions of quality in higher education: input-level conceptions, process-level conceptions, and output-level conception. Finally, Harvey and Green's (1993) conceptual framework for defining quality guided the generation of the three themes of quality (quality as transformation, quality as fitness for purpose, and quality as exceptional).

To meet ethical requirements, we sought informed consent from the participants before the interviews were conducted. Each participant's name was substituted with a pseudonym to keep the database anonymous. Finally, during data analysis and report writing, codes were used to identify the participants in the study based on discipline followed by a sequence in which the interviews were conducted, with LAE standing for lecturer in arts education; LBDS connoting lecturer in bachelor of dental surgery; LCE representing lecturer in civil engineering; LEE symbolizing lecturer in electrical engineering; LMD indicating lecturer in music and drama; LDS representing lecturer in development studies; and LSE denoting lecturer in science education.

The credibility of the findings was ensured through two strategies: member checking and purposive sampling. Member checking into the findings-obtaining feedback on data interpretations and conclusions from the participants-is considered to be "the most critical technique for establishing credibility" (Lincoln \& Guba 1985, p. 314) of qualitative research. Member checking was performed through providing a copy of the draft report to five academics and requesting that they identify any possible distortions or misrepresentations. Nevertheless, only two academics provided feedback on the draft report. Finally, credibility of the findings was ensured through purposeful sampling. The participants were selected purposively, and this allowed for collection of data from information-rich sources.

\section{Results: Academics' Conceptions of Quality in Higher Education}

Transformation, fitness for purpose, and exceptional notions of quality were explicit in the data. The resultant conceptions of quality in higher education by academics are presented below.

\section{Quality as Transformation}

The transformative (or value-added) view of quality was explicit in the responses of academics and emerged as the second dominant theme. All the participants perceived quality in higher education through the lens of transforming students (in terms of knowledge, skills, and personal attributes) as a consequence of the higher education experience. Within the transformative perspective of quality, the participants opined that the higher education experience should be capable of creating a noticeable difference between a university graduate and a nongraduate. Specifically, a lecturer in music and drama said:

But skills is [sic] really important. What skills are we really giving to these students? What are we giving this person (the student) that they [sic] can do out there that someone who has not come to Makerere University can't do? This is the thing that should lead us. (LMD2)

All academics, except the lecturer in development studies, held similar views on the imperative to develop subject or technical skills among students. To justify this imperative, a lecturer in dental surgery said: "In the area where we are, we are very technical people. I mean I am a dental surgeon and we have technical skills, whether you like it or not" (LBDS-1). Another participant stated: "When it comes to professions, it [higher education] is actually to equip 
someone with the necessary knowledge and skills for whatever profession they [sic] hope to be in" (LBDS-2).

Contrarily, a lecturer in development studies dismissed the idea that higher education should be concerned with developing subject skills among students. He argued that higher education should be concerned with shaping students' critical thinking abilities rather than developing subject skills, which would amount to vocationalizing the university. The lecturer illustrated:

... skills! That one now is a different thing. There is ... this tendency to vocationalise the university. It is market-driven ... to think that a university graduate should have [subject] skills and that it is the absence of skills that makes university education irrelevant, which to me is a very funny [erroneous] argument. Graduates are not technicians; they are primarily thinkers. (LDS-1)

On whether Makerere University should be preoccupied with developing critical thinking skills among students, a lecturer in music and drama said:

Yes, I don't dispute the fact that universities should produce [critical] thinkers because before you do [something] you have to think. So, for me I think that is taking us back to the basics. Yes ... we need them (critical thinking skills) but beyond that, are we simply going to ... produce thinkers? Does the world out there require thinkers or it requires doers? So I think the argument that we are going to vocationalise [the university], I find it simplistic. I don't think Uganda is developed to the level of just having thinkers; no, we need people (graduates) who are doers (LMD-2).

The dissonance in opinion between a lecturer in development studies and academics from applied disciplines exposes the idea that members of the same stakeholder group (academics) may agree on a notion of quality (e.g., transformation) but hold divergent perspectives on the nature of transformation (e.g., subject skills as opposed to critical thinking). One insight from the foregoing contestation is that academics from applied disciplines subscribed to the teaching of subject skills to students, while an academic from development Studies, a liberal and basic discipline, argued against the teaching of such skills. This discourse provides evidence that the disciplinary affiliation may have an influence on how academics perceive quality in higher education. It further indicates that the perceived purpose of higher education may influence the conception of quality in higher education and the nature of skills higher education should develop.

All academics opined that, in addition to subject skills, students should acquire generic skills and personal attributes during their university experience. Nevertheless, the value attached to generic skills by academics varied from discipline to discipline. Specifically, health sciences (nursing and dentistry) identified problem-solving, lifelong learning, and interpersonal and communication skills as essential generic skills. However, problem-solving and lifelong learning skills (learning how to learn) appeared to be the most highly regarded skills for the health sciences. The inclination towards these skills cannot be divorced from the nature of the health sciences. Undoubtedly, problem-solving and lifelong learning skills are essential for nurses, dental surgeons, and medical practitioners in general. Nurses and dental surgeons deploy problemsolving skills to find answers to patients' problems. A lecturer in dental surgery attested to this by asserting: "For us [health workers], life is about solving problems ... I mean our work is about solving problems" (LBDS-2). 
Concerning lifelong learning skills, it is a recognized fact that the modes of diseases and treatment are always changing, and health care professionals need to keep abreast of shifting trends in their fields of study. In other words, change was recognized as the only constant:

... the mode of diseases change, the treatments change; everything changes, the way things are done changes. There are certain things I was taught when I first came here [to Makerere University] as a student nurse which have changed completely. So, if you don't continue to search for knowledge, then you can be out of practice. (LND-1)

Lifelong learning skills presuppose the idea that health practitioners are not exempt from learning on completion of their degree programs. This will do away with the temptation of offering old solutions to current or new challenges.

On the other hand, interpersonal skills were deemed necessary because nurses and dental surgeons are required to work collaboratively with other professionals, such as laboratory technicians, radiologists, and dieticians, as well as with patients. To emphasize interpersonal skills, a lecturer in nursing posed the following challenge:

If you are a nurse on the [medical] ward and you do not have [good] interpersonal skills, how will you deal with the doctor, deal with the lab attendant, how would you deal with the radiologist and then you must also deal with the dietician because your patient must eat specific foods? (LND-1)

The challenge emphasizes the role of teamwork in effective health care delivery. The needs of clients, nurses, and dental surgeons are better met through effective inter-professional collaboration or the use of multidisciplinary teams.

Engineering academics, just like their health counterparts, emphasized problem-solving skills. A lecturer in electrical engineering aptly put it thus:

Engineering is about looking at real-life situations and devising solutions from an engineering perspective. So a good student or a person who has got the lessons well is one who is able to apply what he has gotten from the class to the real-life situations around him and solve the problems there using the techniques that have been imparted [to him]. So, in that case, we evaluate the quality or goodness of someone who has been taught here by the ability of ... students to actually develop their own solutions. (LEE-2)

This consensus among engineering academics around problem-solving as a key competence for engineering students is attributable to engineers devoting their professional lives to providing creative solutions to problems. Other generic skills that engineering academics deemed essential are critical thinking and innovation. Nevertheless, these skills were not regarded as an end in themselves. Engineering academics were unequivocal on critical thinking and innovation as essential skills based on the premise that these skills lead to the resolution of problems and contribute to the design of new products. Education and performing arts academics identified interpersonal skills, while a development studies academic was emphatic on critical thinking.

Finally, academics raised the issue of personal attributes. In this regard they considered quality education as being concerned with producing a well-rounded person. This presupposes the idea that the transformation of students is not only restricted to development of new knowledge and skills; it extends to the cultivation of attitudes and values in students. The personal attributes 
that were identified by academics include honesty, integrity, ethics, perseverance, and commitment. A lecturer in electrical engineering described it as follows:

Quality education would be looking at the whole product (graduate), not the aspects of education alone ... not only the academic aspects alone, but also the social aspects and morals. So someone [who is] educated would definitely entail a well-rounded character. We actually consider him well formed, not only the academic knowledge but also the social aspects and morals. So, we look at values like integrity and also the diligence and of course commitment ... (LEE-2)

This excerpt suggests that the university should pay considerable attention to the development of students' general character. Similarly, some academics believed that the education system in Uganda was not doing much to develop the students' general character. A lecturer in electrical engineering said, "We are not teaching honesty, we are not teaching accountability. Unfortunately, it is not only Makerere [University], the whole [education] system right from primary [school]" (LEE-1). This excerpt and the previous one indicate the gaps in Makerere University's curriculum.

\section{Quality as Fitness for Purpose}

Fitness for purpose was the dominant conception of quality. Except for an academic in development studies, the rest of the academics alluded to fitness for purpose in their descriptions of quality in higher education. The reluctance of the development-studies academic to subscribe to fitness for purpose can be explained by his perception that the notion amounts to negating the traditional purpose of higher education and occasioning consumerization of higher education. However, the perception of fitness for purpose hinged on three aspects: congruence between the knowledge, skills, and attitudes developed among students with the needs of the workplace; the competitiveness of graduates of a higher education institution or an academic program in the labor market; and higher education's responsiveness to national, regional, and global needs. The three perspectives can be encapsulated in the relevance of higher education. A lecturer in science education provided a rich perspective on quality that attests to the first aspect:

We are always concerned that: do the people who go through our hands gain the knowledge, the skills and develop positive attitudes to their work when they have left [the university]? So, that is a measure of quality as far as I am concerned. So, when we talk about quality I am more or less interested that my students should be able to demonstrate that they have acquired the knowledge, the skills and the attitudes for their places of work. (LSE-1)

This excerpt comprises a transformative element (gaining knowledge and skills and developing positive attitudes) but also an important fitness for purpose dimension (for their places of work). The transformative nature of the statement notwithstanding, it has a significant fitness for purpose dimension. The dilemma of drawing a dividing line between the two competing notions exemplifies the idea that the categories used to classify a perception of quality in higher education are not mutually exclusive.

Regarding the competitiveness of graduates of a higher education institution, one participant was of the view that currently the labor market prefers graduates of specific disciplines at the different universities. According to this participant, some employers prefer education graduates of Kyambogo University and business administration graduates of Nkozi University: 
The yardstick for measuring the quality [of higher education] here would be: What type of graduates are we producing? Can they compete favorably on the outside market with the others? For example, the teachers we produce here, people (employers) are beginning to prefer the Kyambogo [University] ones (teachers); that the Kyambogo [University] ones are better [and] more professional than these ones. So, if you go for a teaching interview and you are a Kyambogo [University] graduate and you are from here [sic], you have a disadvantage. (LAE-2)

Therefore, the competitiveness of graduates of a particular higher education institution in the highly saturated labor market was regarded as an indirect indicator of the quality of higher education. The same lecturer elucidated how employers prefer graduates of a certain private university when it comes to hiring graduates of business studies:

Then I hear for Business Studies, someone (an employer) would rather go for Nkozi (Uganda Martyrs University) graduates. I just hear employers comment that if I am at [sic] an interview panel and I have a Nkozi (Uganda Martyrs University) student (graduate) and a Makerere [University] one, I would rather take the Nkozi (Uganda Martyrs University) one. (LAE-2)

These two excerpts point to one interesting revelation: the quality of academic programs of a university, and consequently the quality of graduates, can vary from discipline to discipline.

The third aspect of fitness for purpose concerns higher education's responsiveness to national, regional, and global contexts. This alludes to the recognition of higher education as an instrument of socioeconomic development. A lecturer in music and drama puts it succinctly:

I think quality higher education is that [education] which is responsive to the national needs and not just national [needs] but also global [needs] because as a university, we are not only producing [graduates] for Uganda but we are producing for the region, the region being East Africa. We are producing for Africa and we are producing for the world. Makerere [University] has certainly people that have gone beyond the boundaries of the country and they are contributing to the development of different countries globally. (LMD2)

Under the third aspect, academics equally deconstructed relevance in terms of the ability of a higher education system or institution to produce graduates who can solve contemporary societal problems. Accordingly, a lecturer in civil engineering described quality higher education as "education that helps you to solve real problems of society" (LCE-2). It can, therefore, be concluded that quality engineering education should contribute to the resolution of societal problems or to making society better through research and technological innovation.

Finally, relevance was viewed in terms of higher education meeting the expectations of the end users of graduates. A lecturer in civil engineering alluded to this: "Quality higher education is that type of education which is tailored to the expectations of the person who is going to use the product (graduate)" (LCE-1). In the context of higher education, students are regarded as products while employers are presumed to be consumers of the products. In this regard, quality in higher education connotes the type of education that meets the expectations and needs of the end users of graduates. This is a consumerist perspective of quality which assumes that employers should define their needs or expectations and higher education institutions should design and deliver programs that meet these expectations. 


\section{Quality as Exceptional}

Exceptional was the final viewpoint of quality by academics. Five academics subscribed to the exceptional notion of quality. However, the voice of the lecturer in development studies overshadowed the voices of academics from other disciplines. Interestingly, all the three variants of exceptional (exclusivity, excellence, and conforming to minimum standards) were apparent in the responses of academics. The exclusivity variant of quality as exceptional was exhibited in preference for low student participation rates in higher education as opposed to massification. A lecturer in development studies affirmed: "[Y]ou can't have everybody pursue university education. You [will] find that about 30 per cent of the students that we have [at Makerere University] are supposed to have gone to vocational and technical institutions" (LDS-1). This elitist view of quality is grounded in the supposition that small means quality and is at odds with the drive to increase access to and participation in higher education.

The second dimension of exclusivity was apparent in the preference for selective student intake. According to a lecturer in development studies, selective intake would enable the admission of "students who are well qualified and well-suited to undertake higher education" (LDS-1). The lecturer advocated for selective intake because it guards against granting access to students who are ill prepared to undertake university education which militates against quality improvement. The preference for selective intake did not take place in a vacuum; it was influenced by the perception that the academic preparedness of students at secondary level has been grossly undermined and the lecturer's prior experience with elite education. Regarding the poor academic preparedness of students, two lecturers were of the view that most secondary schools have abdicated the objectives of secondary education (laying the foundation for further education and enabling individuals to develop the personal skills of problem-solving, information gathering and interpretation, and independent reading and writing) and assumed the role of preparing students to pass terminal examinations. A lecturer in science education described this scenario as "destroying our [lower] education system" (LSE-1).

As a result of the poor academic preparedness at secondary-education level, university students exhibit significant deficiencies in skills that are assumed to be an automatic outcome of secondary schooling and are a predictor of success at university. A lecturer in development studies attested to this mismatch between what secondary schools are supposed to do and what they actually do:

Look at secondary schools! Many of them have stopped teaching and they are only teaching students for passing [exams]. Students don't read; they only read pamphlets of question and answer. And they come here [to university] allegedly having passed so highly; these private schools having outshined the traditional [public] schools. But you bring them here, you put them in [the Bachelor of] Law[s] [program], they all fail ... Some of us are even thinking of having entrance exams. And they come here, they have no culture of reading and really instead of understanding, they have narrowed to question and answer. (LDS-1)

The above excerpt also shows that some lecturers feel that pre-entry examinations should be used to sieve out those who are unqualified for university education and to reduce the failure rate. This is so because the completion rate is regarded as a measure of quality in higher education. 
The lecturers equally perceived quality in terms of excellence. Lecturers described the excellence notion across various disciplines using adjectives such as quality, right, best, qualified, and good. A lecturer in nursing described it as follows:

It is hard to define [quality higher education] but I will try to explain [it]. I would perceive quality education as [one where] ... the right students are selected. Then there are the right teachers: teachers who are knowledgeable and skilled to pass on that knowledge. There are facilities, such that at the end of the day if you have set out that by the end of this period, these students should have acquired A, B, C skills, which should be well articulated, then I would imagine that there is quality education. (LDN-1)

Though this description of quality emphasizes skills, which suggests transformation, emphasis on the right caliber of students and teachers as well as appropriate facilities leans more toward excellence than transformation. A lecturer in civil engineering gave a similar description of quality but introduced an element of the right curriculum. According to him, quality education is one where "students have gone through the right curriculum in terms of content, the curriculum must have been implemented by the qualified staff [and] supplemented by good literature in the library and laboratories for courses that have practical aspects" (LCE-2). The two descriptions of quality relate to the input-process dimensions and assume that a quality output (graduate) would automatically emerge once the inputs and process are up to the required standards.

Excellence, a variant of quality as exceptional, was also perceived in terms of having the best lecturers. A lecturer in development studies said: "Fortunately, Makerere [University] has very high quality [academic] staff; extremely high quality [teaching staff]. I told you that nearly 80 per cent [of academic staff] are trained from first class international universities" (LDS-1).

Finally, excellence was interpreted in terms of the regional and global ranking of the university. A lecturer in development studies alluded to the rankings: "Yes [with] Makerere University, the ranking is high but I think there are so many factors that make it high" (LDS-1). Focusing on ranking presents the university with twin challenges: enhancing international standing and ensuring higher education's relevance to societal needs.

We find it interesting that academics identified with a non-elitist definition of excellence. This is manifested in terms of having "a vibrant teaching and learning environment" (LDS-1) and having adequate learning resources. In the context of engineering education, a study participant described excellence in terms of having equipment that is similar to what is found in industry: "Of course we cannot forget to mention facilities in terms of laboratories which are very close to what is in industry so that the time spent in industry and training these people (students) again is not high" (LEE-2). This non-elitist perspective was influenced by the poor teaching and learning environment and the lack of equipment or the availability of obsolete equipment. This underscores the idea that the problems that academics face influence their conception of quality in higher education. In such instances their conception of quality is normally based on the ideal situation.

Quality in higher education was also perceived in terms of conforming to minimum standards set by a higher education institution or those that may be set by a higher-education regulatory agency. To support this view, a lecturer in music and drama, when asked about what quality in higher education meant, replied that "quality higher education must meet the [minimum] standards of the [higher education] institution ... and government [regulatory agency for higher education]" (LMD-1). Inherent in this conception of quality is the idea that every higher education institution must have internal standards and norms against which it should regularly assess quality. 


\section{Discussion and Conclusions}

The views of academics on quality in higher education focused on three notions of quality: transformation, fitness for purpose, and exceptional. Nevertheless, the more we attempted to arrive at a solitary definition, the more difficult our efforts appeared. Failure to arrive at a solitary definition of quality corroborates the assertion by Wittek and Kvernbekk (2011, p.682) that searching for an "essentialism, once-and-for-all definition" of quality is a waste of time. The transformative view of quality by academics corroborates the findings by Watty $(2005,2006 \mathrm{~b})$ and Zachariah (2007) that academics in the United Kingdom, Australia, and Oman perceived quality in terms of transformation. The convergence in perception of quality as transformation among academics at Makerere University and academics from other cultural settings is attributable to academics being internal stakeholders in universities. Becket and Brookes (2005) posit that internal stakeholders are likely to view quality in higher education as transformation. The transformative perspective of quality was scarcely surprising, because mind development is the traditional responsibility of universities. Within the transformative perspective of quality, a novel finding is that an academic discipline has generic skills aligned with it and this lends credence to the findings of previous studies (Nabaho, 2017; Wickramasinghe \& Perera, 2010).

Besides the transformative view of quality, academics perceived quality in higher education as fitness for purpose. Academics' conception of quality as fitness for purpose resonates with extant studies (Brown, 2010; Lomas, 2007; Villanueva, 2012; Zachariah, 2007). Perceiving quality through the lens of fitness for purpose or relevance is consistent with the current thinking in Uganda. For example, Kasozi (2003) considers relevance to be a sine qua non of quality in higher education. Specifically, Kasozi (2003, p.125) argues: "The relevance of [higher] education to any given society should, and must, be one of the major indicators of quality [in higher] education." The dominance of fitness for purpose as a perspective of quality in higher education signifies a mutation from higher education's traditional purpose of promoting "knowledge, truth and reason" (Barnett, 2003, p. 2) to "more functional notions of the relationship between higher education and society" (Brown, 2010, p. 69). Arguably, Idrus's (2003, p. 150) assertion that "the definition of quality as fitness for purpose has shown to be potent in developing an educational policy and educational practices to help the countries climb out of their chronic and potentially crippling predicaments" explicates the stakeholders' predisposition toward fitness for purpose. In transitional economies, governments recognize higher education as an instrument for creating the intellectual muscle needed to leapfrog the multiple developmental challenges. Our findings suggest that the stakeholders' perception about higher education's purpose implicitly influences their conceptualization of quality in higher education. This corroborates Barnett's (1992, p. 5) assertion that "behind our sense of what constitutes quality, there lies-whether explicitly formed or tacitly held-as the ends that higher education should serve."

Perfection/consistency (or zero defects) did not feature in the academics' descriptions of quality in higher education. This could be attributed to the dominant view in the academy that consistency is applicable in industrial settings because higher education does not aim at producing defect-free graduates (Lomas, 2002). However, this does not mean that consistency is irrelevant to the higher education enterprise; it is appropriate for administrative processes in higher education, such as the maintenance of student records (Harvey \& Knight, 1996).

Previous studies unearthed interstakeholder contestations around Harvey and Green's (1993) typology of quality. This article contributes to scholarship on quality in higher education by unveiling intrastakeholder competing voices regarding the variants of particular notions of quality in higher education. While academics could agree on a definition of quality, they would express 
opposing views either about variants of the notion or the form the variants should take. For example, a development studies academic argued that higher education should be preoccupied with developing critical thinking skills because university graduates are expected to be thinkers rather than technicians. The perspective of the lecturer in development studies validates his unquestionable commitment to higher education's traditional purpose of improving the minds of students. Thus, ardent promoters of higher education's traditional purpose are likely to wrestle with attempts to promote a nexus between the university and the world of work on account of such attempts amounting to anti-intellectualism and relegating higher education to skills training. The opinion of the development studies academic in relation to skills training in higher education corroborates the assertion by the Task Force on Higher Education and Society (2000) that liberal or general education focuses on cognitive skills as opposed to psychomotor skills, and that it is concerned with "teaching people how to think [critically] and to learn [how to learn]" (p. 84). It is, therefore, probable that an academic discipline can tacitly influence stakeholders' conceptions of quality.

In the quality discourse, it is difficult to exclusively classify academics' conceptions of quality into the transformative and fitness for purpose categories. It is unavoidable for these seemingly discrete categories to overlap. The classification dilemma between the notions is consistent with Watty's (2003) assertion that the notions of quality have the "potential to overlap at the margin" and that "stakeholders' conceptions of quality may not 'fit' only one of the five categories" (p. 214). The classification dilemma begs a fundamental question: Can transformation be implied in fitness for purpose and vice versa? Extant literature provides diametrical guidance on the matter. Advocates of fitness for purpose, such as Woodhouse (2006), argue that fitness for purpose is the definition for all seasons because the alternative notions of quality in higher education can be encapsulated into it. On the other hand, Harvey and Knight (1996) consider transformation to be the meta-quality concept because it presupposes a fundamental purpose of higher education and alternative notions of quality are mere operationalizations of the transformative notion. We subscribe to Harvey and Knight's (1996) rationalization of transformation as the meta-quality concept because the transformative perspective of quality provides a reliable benchmark or reference point against which the fitness of the graduate for the world of work is measured. Therefore, fitness for purpose merely provides evidence of the degree of transformation.

The classification impasse and the contestations surrounding the quality concept should motivate the search for a notion of quality that can accommodate both fitness for purpose and transformation. From the findings, we suggest quality as responsiveness to be a middle of the road notion. The central premise of our notion is that the world of education and the world of work cannot, in the contemporary age, be treated as diametrical, and the divide between higher education's traditional and contemporary purposes is unsustainable. In other words, there is a need to ensure a nexus between the two worlds. This nexus can be strengthened by higher education institutions responding to the needs of society and producing graduates with a high degree of labor market readiness. While we subscribe to transformation as higher education's fundamental purpose, we are cognizant that transformation is not for its own sake. As Stensaker and Rosa (2007) aptly put it, the aim of the undergraduate higher education experience is to transform students "from adolescents with school-type knowledge into adults ready to enter society and the labor market at the highest level of competencies available" (p. 7). Similarly, the research (or knowledge generation) mission of the university can be nested into responsiveness if it is nation-centered as well as contributing to the resolution of societal problems. However, the third mission of the university would be responsive on account of being community-centered. Within this same notion, the teaching activity can be considered responsive if it is studentcentered. 
The responsiveness notion of quality has potential to narrow the conceptual divide between higher education's traditional and contemporary purposes. For instance, while supporters of the traditional purpose argue that higher education should develop graduates who can think critically and are predisposed toward lifelong learning, the labor market is hungry for these skills. In the African context, the notion of quality as responsiveness would address the employers' concerns that university graduates are ill-prepared for the labor market. The rampant unemployment in Africa is fueled in part by the mismatch between the skills that the employers require and the skills of university graduates. Therefore, quality as responsiveness has potential to inform education policies for narrowing the gap between the academy and the world of work.

The findings are important for both theory and practice. In terms of theory, it can be inferred that academics' perceptions of quality do not take place in a vacuum. The perceived purpose of higher education and the problems that higher education institutions (and systems) face are critical antecedents of the stakeholders' perceptions of quality in higher education. Regarding higher education's purpose, the stakeholders' competing voices relating to quality are occasioned by their sense-making of higher education's purpose. This suggests that higher education's purpose should be a precursor to understanding the stakeholders' perception of quality higher education as well as assessing quality. Regarding the problems within a higher education system, the employability of graduates, the quality of inputs (students, lecturers, and learning resources), and the perceptions of employers about the quality of graduates have a bearing on stakeholders' perceptions of quality in higher education. Another theoretical insight is the difficulty of arriving at a solitary definition of quality in higher education. Therefore, the multidimensional nature of quality should be respected, and the indicators of quality in higher education should encompass the three perspectives of quality which also appear in previous studies. On the practical front, the multidimensional nature of quality in higher education calls for a multidimensional approach to assuring and assessing it. Finally, program design and instructional strategies, as well as assessment practices, in higher education institutions should be sensitive to discipline-specific generic skills. At program level, applied academic disciplines should balance subject-specific and generic skills, student-centered approaches should be employed because of their potency to develop both subject-specific and generic skills, and assessment practices for applied disciplines should also pay attention to generic skills.

This article contributes to the quality discourse in the higher education systems of developing countries. First, Schindler et al. (2015) rightly assert "one must know what quality [higher education] is before determining how to assure it" (p. 7). Based on the three perceptions of quality by academics, literature exists that has the potential to inform the design of a theoretical framework for developing quality assurance systems aligned with the context of developing countries. Second, the article provides perceptions of quality in higher education from the African cultural context. In terms of the direction for further research, we propose a replication study in a private university with a view to ascertaining whether the conception of quality by academics varies across academics in public and private universities.

\section{References}

Alshamy, A. S. A. (2011). Funding mechanisms and quality assurance systems in higher education in Egypt in comparative perspective (Unpublished doctoral thesis). University of Birmingham, United Kingdom. GS Search 
Barandiaran-Galdós, M., Barrenetxea Ayesta, M., Cardona-Rodríguez, A., Mijangos del Campo, J., \& Olaskoaga-Larrauri, J. (2012). What do teachers think about quality in the Spanish university? Quality Assurance in Education, 20(2), 91-109. https://doi.org/10.1108/09684881211219352 GS Search

Barnett, R. (1992). The idea of quality: Voicing the educational. Higher Education Quarterly, 46(1), 3-19. https://doi.org/10.1111/i.1468-2273.1992.tb01581.x GS Search

Barnett, R. (2003). Beyond all reason: Living with ideology in the university. Buckingham, UK: Society for Research into Higher Education and Open University Press. GS Search

Becket, N., \& Brookes, M. (2005). Analysing quality audits in higher education. Brookes eJournal of Learning and Teaching, 1(2), 1-12. GS Search

Boyle, P., \& Bowden, J. A. (1997). Educational quality assurance in universities: An enhanced model. Assessment \& Evaluation in Higher Education, 22(2), 111-121. https://doi.org/10.1080/0260293970220202 GS Search

Brown, V. (2010). How university academics respond to the introduction of new quality assurance policies in South African higher education (Doctoral thesis, University of Pretoria, South Africa). Retrieved from https://repository.up.ac.za/handle/2263/24941 GS Search

Campbell, C., \& Royzsnyai, C. (2002). Quality assurance and the development of course programmes. Bucharest: UNESCO. GS Search

Cardoso, S., Rosa, M. J., \& Stensaker, B. (2016). Why is quality in higher education not achieved? The view of academics. Assessment \& Evaluation in Higher Education, 41(6), 950-965. https://doi.org/10.1080/02602938.2015.1052775 GS Search

Creswell, J. W. (2003). Research design: Qualitative, quantitative, and mixed methods approaches (3rd ed.). London: Thousand Oaks. GS Search

Doherty, G. D. (2008). On quality in education. Quality Assurance in Education, 16(3), 255-265. https://doi.org/10.1108/09684880810886268 GS Search

Elassy, N. (2015). The concepts of quality, quality assurance and quality enhancement. Quality Assurance in Education, 23(3), 250-261. https://doi.org/10.1108/QAE-11-2012-0046 GS Search

Ezati, B. A., Opolot-Okurut, C., \& Ssentamu, P. N. (2014). Addressing pedagogical training needs of teaching staff: Lessons from Makerere University short professional development program 2006-2010. American Journal of Educational Research, 2(12), 1190-1198. https://doi.org/10.12691/education-2-12-9 GS Search

Giertz, B. (2000, August). The quality concept in higher education. Paper presented at the TQM for Higher Education Institutions II, Verona, Italy. GS Search

Green, D. (1994). What is quality in higher education? Buckingham, UK: Society for Research into Higher Education and Open University Press. GS Search

Harvey, L., \& Green, D. (1993). Defining quality. Assessment and Evaluation in Higher Education, 18(1), 9-34. https://doi.org/10.1080/0260293930180102 GS Search 
Harvey, L., \& Knight, P. T. (1996). Transforming higher education. Buckingham, UK: Society for Research into Higher Education and Open University Press. GS Search

Idrus, N. (2003). Transforming quality for development. Quality in Higher Education, 9(2), 141150. http://dx.doi.org/10.1080/13538320308154 GS Search

Jonathan, L T. (2000). Quality assurance and evaluation in African universities: Developing a sustainable quality culture in a challenging environment. South African Journal of Higher Education, 14(2), 45-49. GS Search

Jungblut, J. P. W., Vukasovic, M., \& Stensaker, B. (2015). Student perspectives on quality in higher education. European Journal of Higher Education, 5(2), 157-180. https://doi.org/10.1080/21568235.2014.998693 GS Search

Kadhila, N. (2012). Quality assurance mechanisms in higher education institutions in Namibia (Doctoral thesis, University of the Free State, Bloemfontein, South Africa). Retrieved from http://scholar.ufs.ac.za:8080/xmlui/handle/11660/979 GS Search

Kalayci, N., Watty, K., \& Fahriye, H. (2012). Perceptions of quality in higher education: A comparative study of Turkish and Australian business academics. Quality in Higher Education, 18(2), 149-167. http://dx.doi.org/10.1080/13538322.2012.697671 GS Search

Kasozi, A. B. K. (2003). University education in Uganda: Challenges and opportunities for reform. Kampala: Fountain Publishers. GS Search

Lincoln, Y. S., \& Guba, E. G. (1985). Naturalistic inquiry. Beverly Hills, CA: Sage. GS Search

Liu, S. (2016). Quality assurance and institutional transformation: The Chinese experience. https://doi.org/10.1007/978-981-10-0789-7 GS Search

Lomas, L. (2002). Does the development of mass education necessarily mean the end of quality? Quality in Higher Education, 8(1), 71-79. http://www.tandfonline.com/doi/abs/10.1080/13538320220127461 GS Search

Lomas, L. (2007). Zen, motorcycle maintenance and quality in higher education. Quality Assurance in Education, 15(4), 402-412. https://doi.org/10.1108/09684880710829974 GS Search

Makerere University, Directorate of Quality Assurance. (2013). Makerere University selfassessment report. Kampala: Makerere University.

Mamdani, M. (2007). Scholars in the marketplace: The dilemmas of neo-liberal reform at Makerere University, 1989-2005. Dakar: CODESRIA. GS Search

Martin, M., \& Stella, A. (2007). External quality assurance in higher education: Making choices. Paris: UNESCO/IIEP. GS Search

Materu, P. (2007). Higher education quality assurance in Sub-Saharan Africa: Status, challenges, opportunities, and promising practices (World Bank Working Paper No. 124, Africa Human Development Series). Washington, DC: World Bank. Retrieved from http://documents.worldbank.org/curated/en/601151468204838555/Higher-education- 
quality-assurance-in-Sub-Saharan-Africa-status-challenges-opportunities-and-promisingpractices GS Search

Materu, P., Obanya, P.; \& Righetti, P., (2011). The rise, fall, and reemergence of the University of Ibadan, Nigeria. In Altbach, P. G. \& Salmi, J. (Eds.), The road to academic excellence: The making of world class universities (pp.195-227). https://doi.org/10.1596/9780821388051 CH07 GS Search

Materu, P., \& Righetti, P. (2010). Quality assurance in Sub-Saharan Africa. Research in Comparative and International Education, 5(1), 3-17. https://doi.org/10.2304/rcie.2010.5.1.3 GS Search

Merriam, S. B. (2002). Qualitative research in practice: Examples for discussion and analysis. San Francisco, CA: Jossey-Bass. GS Search

Mhlanga, E. (2008). Quality assurance in higher education in Southern Africa: The case of the universities of the Witwatersrand, Zimbabwe and Botswana (Doctoral thesis, University of the Witwatersrand, Johannesburg, South Africa). Retrieved from http://wiredspace.wits.ac.za/handle/10539/7599 GS Search

Nabaho, L. (2017). Developing generic competences in life sciences: The untold story of the Makerere University College of Health Sciences in Uganda. Tuning Journal for Higher Education, 4(2), 389-406. https://doi.org/10.18543/tihe-4(2)-2017pp389-406 GS Search

Nabaho, L., Aguti, J., \& Oonyu, J. (2016). Assuring the quality of teaching at Makerere University in Uganda: Practices and experiences of academics and students. Alternation, 23(1), 4061. GS Search

Nega, M. (2012). Quality and quality assurance in Ethiopian higher education: Critical issues and practical implications. Twente: Twente University. GS Search

Newton, J. (2002). Barriers to effective quality management and leadership: Case study of two academic departments. Higher Education, 44(2), 185-212. https://doi.org/10.1023/A:1016385207071 GS Search

Pfeffer, N. \& Coote, A. (1991). Is quality good for you? A critical review of quality assurance in welfare services. London: Institute of Public Policy Research. GS Search

Sarrico, C. S., Rosa, M. J., Teixeira, P. N., \& Cardoso, M. F. (2010). Assessing quality and evaluating performance in higher education: Words apart or complementary views? Minerva, 48(1), 35-54. https://doi.org/10.1007/s11024-010-9142-2 GS Search

Schindler L., Welzant, H., Puls-Elvidge, S., \& Crawford, L. (2015). Definitions of quality in higher education: A synthesis of the literature. Higher Learning Research Communications, 5(3), 3-13. https://doi.org/10.18870/hlrc.v5i3.244 GS Search

Shabani, J., Okebukola, P., \& Oyewole, O. (2014). Quality assurance in Africa: Towards a continental higher education and research space. International Journal of African Higher Education, 1(1), 139-171. https://doi.org/10.6017/ijahe.v1i1.5646 GS Search

Task Force on Higher Education and Society. (2000). Higher education in developing countries: Peril and promise. https://doi.org/10.1596/0-8213-4630-X GS Search 
Utuka, G. (2012). Quality assurance in higher education: Comparative analysis of provisions and practices in Ghana and New Zealand (Doctoral thesis, Victoria University of Wellington, New Zealand). Retrieved from http://researcharchive.vuw.ac.nz/handle/10063/2024 GS Search

van der Bank, C. M., \& Popoola, B. A. (2014). Quality assurance: A case study at a university of technology. Mediterranean Journal of Social Sciences, 5(23), 2129-2136. https://doi.org/10.5901/miss.2014.v5n23p2129 GS Search

Vann, M. (2012). Stakeholders' perception of quality in Cambodian higher education (Doctoral thesis, RMIT University). Retrieved from https://researchbank.rmit.edu.au/view/rmit:160093 GS Search

Villanueva, N. N. (2012). Assuring quality in Belizean higher education: A collective case study of institutional perspectives and practices (Doctoral dissertation). Retrieved from http://digitalcommons.unl.edu/cehsedaddiss/83/ GS Search

Vlăsceanu, L., Grüenberg, L., and Pârlea, D. (2007). Quality assurance and accreditation: A glossary of basic terms and definitions. Bucharest: UNESCO-CEPES. GS Search

Vroeijenstijn, A. I. (2006). A journey to uplift quality assurance in the ASEAN universities. Bangkok. GS Search

Watty, K. (2003). When will academics learn about quality? Quality in Higher Education, 9(3), 213-221. https://doi.org/10.1080/1353832032000151085 GS Search

Watty, K. (2005). Quality in accounting education: What say the academics? Quality Assurance in Education, 13(2), 120-131. https://doi.org/10.1108/09684880510594373 GS Search

Watty, K. (2006a). Want to know about quality in higher education? Ask an academic. Quality in Higher Education, 12(3), 291-301. https://doi.org/10.1080/13538320601051101 GS Search

Watty, K. (2006b). Addressing the basics: Academics' view of the purpose of higher education. Australian Educational Research, 33(1), 23-29. https://doi.org/10.1007/BF03246279 GS Search

Westerheijden, D. F., Stensaker, B., \& Rosa, M. J. (2007). Introduction. In D. Westerheijden, B. Stensaker, \& M. J. Rosa (Eds.), Quality assurance in higher education: Trends in regulation, translation and transformation (pp. 1-11). https://doi.org/10.1007/978-1-4020$\underline{6012-0}$ GS Search

Williams, J.(2013). Editorial. Quality in Higher Education, 19(1), 72. http://dx.doi.org/10.1080/13538322.2013.777519

Wickramasinghe, V. \& Perera, L. (2010). Graduates', university lecturers' and employers' perceptions towards employability skills. Education + Training, 52(3), 226-244. https://doi.org/10.1108/00400911011037355 GS Search 
Wittek, L., \& Kvernbekk, T. (2011). On the problem of asking for a definition of quality in education. Scandinavian Journal of Education Research, 55(6), 671-684. https://doi.org/10.1080/00313831.2011.594618 GS Search

Woodhouse, D. (2006, March). Quality = fitness for purpose (FFP): Definition for all seasons. Paper presented at the APQN Conference on Cooperation in Quality Assurance, Shanghai. GS Search

Zachariah, S. (2007). Managing quality in higher education: A stakeholder perspective (Doctoral thesis, University of Leicester, Leicester, UK). Retrieved from https://ra.le.ac.uk/handle/2381/4385 GS Search 